\title{
Archaeological Test Excavations at 41MV57: The Seco Mines Project, Maverick County, Texas
}

\author{
Augustine J. Frkuska Jr. \\ Elizabeth C. Frkuska \\ David Brown \\ Thomas R. Hester \\ Center for Archaeological Research
}

Follow this and additional works at: https://scholarworks.sfasu.edu/ita

Part of the American Material Culture Commons, Archaeological Anthropology Commons, Environmental Studies Commons, Other American Studies Commons, Other Arts and Humanities Commons, Other History of Art, Architecture, and Archaeology Commons, and the United States History Commons

Tell us how this article helped you.

This Article is brought to you for free and open access by the Center for Regional Heritage Research at SFA ScholarWorks. It has been accepted for inclusion in Index of Texas Archaeology: Open Access Gray Literature from the Lone Star State by an authorized editor of SFA ScholarWorks. For more information, please contact cdsscholarworks@sfasu.edu. 


\section{Archaeological Test Excavations at 41MV57: The Seco Mines Project, Maverick County, Texas}

\section{Creative Commons License}

\section{(c) (1) \&}

This work is licensed under a Creative Commons Attribution-NonCommercial 4.0 International License 
ARCHAEOLOGICAL TEST EXCAVATIONS AT 41 MV 57 :

THE SECO MINES PROJECT, MAVERICK COUNTY, TEXAS

Augustine J. Frkuska, Elizabeth C. Frkuska, David Brown, and Thomas R. Hester

Center for Archaeological Research The University of Texas at San Antonio Archaeological Survey Report No. 28 


\section{TABLE OF CONTENTS}

$\begin{array}{lc} & \text { Page } \\ \text { INTRODUCTION } & 1 \\ \text { ARCHAEOLOGICAL BACKGROUND } & 1 \\ \text { OBSERVATIONS ON THE SITE ENVIRONMENT } & 2 \\ \text { THE SITE } & 4 \\ \text { RESULTS OF FIELD INVESTIGATIONS } & 4 \\ \text { SUMMARY AND RECOMMENDATIONS } & 6 \\ \text { ACKNOWLEDGEMENTS } & 6 \\ & \end{array}$

Figures

1. Site 47 MV 57

2. Hearth at Site 41 MV 57 


\section{INTRODUCTION}

In mid-February, 1977, an archaeological field team from the Center for Archaeological Research, The University of Texas at San Antonio, conducted investigations at prehistoric site 41 MV 57 in Maverick County, Texas. The site is located along a tributary of Seco Creek and is to be modified by the installation of a sewage collection system (the Seco Mines Project).

In order to evaluate the site prior to the initiation of this project, it was deemed necessary to carry out a program of intensive surface survey, mapping, and controlled test excavations. This work was carried out under the terms of a contract with the Maverick County Commissioner's Court, facilitated by the firm of Bryant-Curington, Inc. (Austin) and the Texas Water Quality Board.

The site had been originally documented by Hayden Whitsett, archaeologist for the Texas Water Quality Board, during a survey of the Seco Mines project area in late 1976 (Whitsett 1976a). Whitsett's evaluation of this site led to a recommendation for further study (Whitsett 1976b). The Center for Archaeological Research was contacted, and a research plan for work at the site was submitted (Hester 1977) after a visit to the site by Dr. Thomas R. Hester and Fred Valdez, Jr., in January, 1977.

After receiving authorization to proceed with fieldwork at 41 MV 57, a field team consisting of Augustine Frkuska, Elizabeth Frkuska, and David Brown was sent to the site. The investigations conducted by this team were under the general supervision of Dr. Thomas. R. Hester (Director of the Center) and Jack D. Eaton (Research Associate of the Center).

The 1977 fieldwork was oriented toward two main tasks: (1) to evaluate, via intensive surface survey and test pitting, a previously identified archaeological site in terms of its significance and possible eligibility for the National Register of Historic Places; (2) to record and map any archaeological materials at the site that might be destroyed by the proposed Seco Mines Project.

\section{ARCHAEOLOGICAL BACKGROUND}

There has been little in the way of scientific archaeology done in Maverick County. Recent studies have included a survey of an EDA Title $X$ project area (Eagle Pass Main Arroyo Development) and this led to the documentation of four archaeological sites (Jackson and Hall 1976). The sites yielded chipped stone artifacts ranging in age from Late Paleo-Indian times (ca. 6000 B.C.) into Archaic times (ca. 5500 B.C. to A.D. 1200).

J. Parker Nunley, working for the UTSA Gateway Project, conducted two site survey sessions along the Rio Grande in 1975 and 1976. Numerous sites were documented, and the Stockley site, north of Eagle Pass, was extensively tested (Nunley 1975, 1976).

Paul and Susanna Katz (personal communication) conducted limited site survey work in Maverick County during 1975. This was done under contract with Texas Tech University. 
Most recently, Whitsett (1976a, 1976b) conducted a survey of areas to be impacted by the Seco Mines Project. Two sites, 41 MV 57 and 47 MV 58, were recorded. It was Whitsett's survey, under the aegis of the Texas Water Quality Board, that led to the fieldwork described in the present report.

While the culture history of Maverick County can only be dimly discerned at present, we suggest that the following chronological framework is reflected in the archaeological record:

1) Paleo-Indian period (ca. 9200-6000 B.C.): end of Pleistocene and beginning of Holocene (recent); scattered evidence of human occupation in the form of fluted and lanceolate points (Clovis, Folsom, Plainview, Golondrina, and other types).

2) Archaic period (ca. 6000 B.C. to A.D. 1200): persistent hunting and gathering tradition represented by numerous sites with abundant chipped stone artifacts (stemmed and unstemmed dart points, scrapers, choppers, chipped stone refuse).

3) Late Prehistoric period (ca. A.D. 1200-1600): continued hunting and gathering 1 ifeway, but with changes in material culture, particularly the introduction of the bow and arrow and, in some areas, bone-tempered pottery. Heavy emphasis on bison hunting in some localities (e.g. in adjacent Zavala County; cf. Hester 1975).

4) Historic period: intrusion of European populations; establishment of Spanish mission complex at Guerrero in early 18th century (cf. Weddle 1968); decimation of native Indian populations ("Coahuiltecans");

intruding Indian groups in 18th and 19th century, particularly Lipan

Apache; increased European settlement in 19th century (cf. Osborne et al. 1976 regarding architectural remains of this period in Eagle Pass).

\section{OBSERVATIONS ON THE SITE ENVIRONMENT}

Site 41 MV 57 lies within a riparian environment along the eastern side of a tributary of Seco Creek. This tributary has an entrenched channel, and at the time of the January and February visits, water was present in the channe1. Two vegetational communities are noted at the site. One of these (which we term "Zone I") includes the riparian vegetation found along the water course. Species represented in this zone include whitebrush, cottonwood, hackberry, mesquite, prickly pear, a variety of grasses (Whitsett 1976a:1, mentions red gramma, curly mesquite, tobosa, and three-awn), snakeweed, marigold, and other wild flowers and plants. The other major vegetational community ("Zone II") is found on a low, eroded terrace near the tributary. Vegetation in this area includes mesquite, tumbleweed, blackbrush, a 17 thorn, snakeweed, prickly pear, Christmas cactus, hedgehog cactus, star cactus, Yucca, Acaia, and a variety of grasses. Roughly one-fourth of the site area is within Zone I, with the remainder $7 y i n g$ in the Zone II area. 
This page has been

redacted because it

contains restricted

information. 
The soils along the tributary are of the Pryor series, a fine-silty, hyperthermic family of Ustollic Calciorthids. This fine silt is high in $\mathrm{CaCO}_{3}$. It is moderately alkaline, and ranges in color from a grayish brown on the surface to a yellowish hue at approximately one meter in depth. Soil information pertinent to the site area is currently in press, and we thank the local Soil Conservation Service office in Eagle Pass for sharing the data with us.

\section{THE SITE}

The prehistoric archaeological site designated as 41 MV 57 lies on a low terrace and floodplain adjacent to the east bank of an unnamed tributary of Seco Creek (Fig. 1). Construction of the A7ta Verde Molasses Plant has altered the easternmost margin of the site, and modification at the northern end of the site occurred with the construction of Loop 431. The present site area is at least 1000 feet $1 \mathrm{ong}$, and is up to 250 feet in width (cf. Whitsett $1976 a: 1)$.

Surface material in the form of chipped stone debris and burned rock was found to be widely dispersed across the site area. A small concentration of cultural remains was noted at the southern end of the site. Careful surface survey led to the discovery of a small hearth eroding from the top $2-3 \mathrm{~cm}$ of the site deposits (Figs. 1, 2).

\section{RESULTS OF FIELD INVESTIGATIONS}

The initial step in the fieldwork was a thorough surface survey of the site area. A11 artifacts and features (such as the hearth mentioned above) were located and were later plotted on the site map. A permanent datum was established on the Alta Verde Molasses Plant cyclone fence which forms the eastern edge of the site. A plane table and alidade were set up and a map was made of the site.

Particular attention was given to that area of the site along the west side of the Alta Verde fence line. This was a strip approximately three meters wide, paralleling the fence; within this zone, a sewage ma in for the proposed collection system is to be installed. Two test units were placed within this area, (see Fig. 1 for their locations), following the recommendations set forth by Whitsett (1976b). The objective of the testing was to obtain information on subsurface deposits in order to evaluate the impact of the proposed project on any buried cultural resources.

Both of the test units were two-meter squares. Prior to excavation, a11 surface material within the units was mapped in situ. Arbitrary excavation levels $10 \mathrm{~cm}$ in thickness were carried to a depth of $20 \mathrm{~cm}$, and a constant volume sample was taken from the southeast corner of each level. All excavated materials were passed through $1 / 4-$ inch screen. A11 notes and photographs resulting from the field operations are on file at the Center for Archaeological Research. 


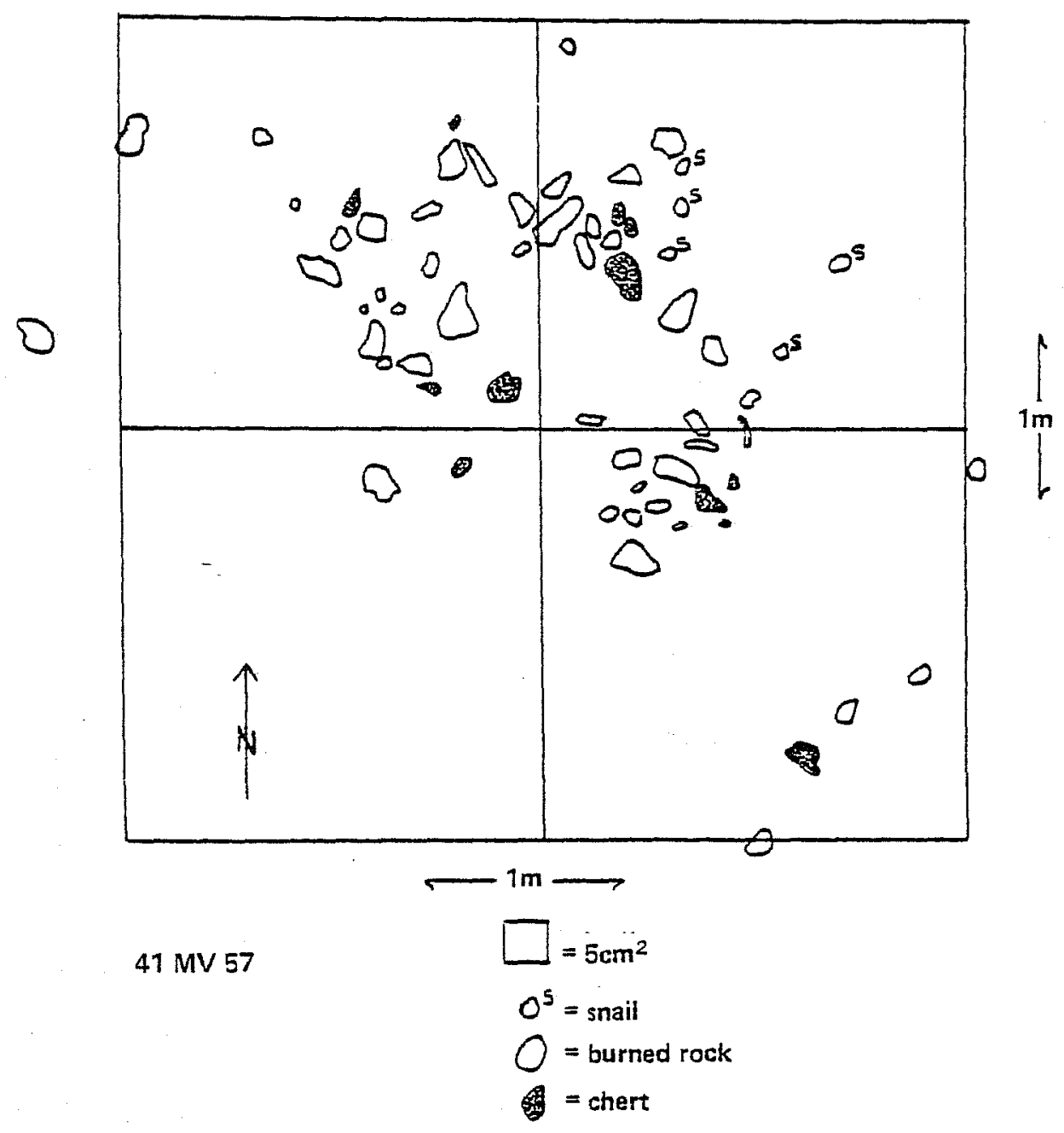

Figure 2. Hearth at Site 41 MV 57. 
Test Unit I

The first test unit was located at the northern end of the proposed route of the sewage main (Fig. T). The $0-10 \mathrm{~cm}$. Tevel revealed a few pieces of burned chert. No other cultural material was found in this excavation unit.

Test unit II

The second test unit was placed at the southern end of the site area over a sma 11 concentration of 7 ithic debris (flakes) and burned rock (Fig. 1). Excavation revealed that most cultural material was 1 imited to the first 10 $\mathrm{cm} 1$ evel of the square, though scattered burned rock was found near the bottom of the $20 \mathrm{~cm}$ level.

\section{SUMMARY AND RECOMMENDATIONS}

In February, 1977, 1imited test excavations were conducted at site 41 MV 57. The goal of the testing was to determine whether or not significant archaeological materials were buried within the proposed route of a sewage main. In addition to test excavations, the field team also prepared a detailed map of the site, and carefully inspected the site surface for additional archaeological information.

The test excavations indicate that scattered archaeological remains (principal1y flakes and burned rock) are confined to the upper $10 \mathrm{~cm}$ of the deposits. This information, combined with that gleaned from surface survey, suggests that the site was used for short-term occupations during the prehistoric period. The time range for these occupations cannot be determined on the basis of present evidence. We do not think that any significant archaeological resources wi11 be affected by this portion of the proposed Seco Mines Project. We recommend that an archaeologist be contacted immediately should any important archaeological evidence be uncovered during the course of construction activities.

ACKNOWLEDGEMENTS

We are grateful to Jack D. Eaton and Lynn Highley for their comments on this report. 


\section{REFERENCES CITED}

Hester, T. R.

1975 Late Prehistoric Cultural Patterns Along the Lower Rio Grande of Texas. Bulletin of the Texas Archeological Society 46:107-125.

1977 Plan of Study. Archaeological Testing at Site 41 MV 57, Seco Mines Project, Maverick County, Texas. Submitted to the Texas Water Quality Board. 2 pp.

Jackson, M. F. and G. D. Hall

1976 Eagle Pass Main Arroyo Development Project: Assessment of its Impact on the Archaeological Resources. Manuscript on file, Texas Archeological Survey, Austin. 5 pp.

Nunley, J.P.

1975 Report of Archaeological Survey Activities, 1975. In: Archaeology and Ethnohistory of the Gateway Area, Middle Rio Grande of Texas, Report of the 1975 Investigations: 40-47. The University of Texas at San Antonio.

1976 Report on the Second Season's Survey of Archaeological Resources in the Vicinity About Guerrero, Coahuila, Mexico. In: Archaeology and Ethnohistary of the Gateway Area: Middle Rio Grande of Texas, Report of the 1976 Investigations (assembled by $R$. E. W. Adams): 38-41. The University of Texas at San Antonio.

Osborne, L. et al.

1976 Report on the Architectural Survey of Villa Guerrero, Coahuila, Mexico and Eagle Pass, Texas, United States. University of Texas at Austin, School of Architecture.

Weddle, R. S.

1968 San Juan Bautista, Gateway to Spanish Texas. University of Texas, Austin.

Whitsett, W. H.

1976a An Archeological Reconnaissance at Seco Mines, Maverick County (C-48-1311-02). Report on file, Texas Water Quality Board. 7 pp.

1976b Proposed Archeological Testing Program at Seco Mines, Maverick County, Maverick County Commissioner's Court, (C-48-1311-02). Report on file, Texas Water Quality Board. 2 pp. 